\title{
BMJ Open Retrospective study of patterns of vitamin $D$ testing and status at a single institution paediatric orthopaedics and sports clinics
}

\author{
Susan Mahan (D , , Kathryn Ackerman, ${ }^{1}$ Rachel DiFazio, ${ }^{1}$ Patricia Miller, ${ }^{1}$ \\ Lanna Feldman, ${ }^{1}$ Nicholas Sullivan, ${ }^{1}$ Michael Glotzbecker, ${ }^{2}$ Ingrid A Holm ${ }^{3}$
}

To cite: Mahan S, Ackerman $\mathrm{K}$, DiFazio R, et al. Retrospective study of patterns of vitamin $D$ testing and status at a single institution paediatric orthopaedics and sports clinics. BMJ Open 2021;11:e047546. doi:10.1136/ bmjopen-2020-047546

- Prepublication history for this paper is available online. To view these files, please visit the journal online (http://dx.doi. org/10.1136/bmjopen-2020047546).

Received 02 December 2020 Accepted 11 November 2021

Check for updates

C Author(s) (or their employer(s)) 2021. Re-use permitted under CC BY-NC. No commercial re-use. See rights and permissions. Published by BMJ.

${ }^{1}$ The Department of Orthopaedics and Sports Medicine, Boston Children's Hospital, Boston, Massachusetts, USA

${ }^{2}$ Department of Orthopaedics, UH Rainbow Babies and Children's Hospital, Cleveland, Ohio, USA

${ }^{3}$ Department of Endocrinology, Boston Children's Hospital, Boston, Massachusetts, USA

Correspondence to

Susan Mahan;

susan.mahan@childrens.

harvard.edu

\section{ABSTRACT}

Objective(s) There has been a recent increase in awareness of the importance of bone health in children treated by paediatric orthopaedic and sports medicine providers. The purpose of this study was to assess our utilisation of 25 hydroxy vitamin $D(25(\mathrm{OH})$ Vit $D)$ testing in the past 10 years, and to evaluate the level of $25(\mathrm{OH})$ Vit $\mathrm{D}$ sufficiency in various populations of patients seen.

Design This is a single site, retrospective medical record review study.

Setting The study took place at a single large, private, paediatric level 1 trauma teaching hospital in the Northeast USA.

Participants Our internal medical records query system identified all patients who have had $25(\mathrm{OH})$ Vit $\mathrm{D}$ testing in the past 10 years, from 1 January 2009 to 31 December 2018.

All patients included were seen on an outpatient basis at our Orthopaedic clinics.

Interventions No interventions for strict research, however, eligible patients have had 25(OH)Vit D testing during their standard of care treatment.

Main outcome measure(s) The varying number of $25(\mathrm{OH})$ Vit $D$ testing that occurred over the study time period within Orthopaedic groups, and by Vit D levels as sufficient, insufficient and deficient. 25(OH)Vit D sufficiency was $\geq 30 \mathrm{ng} /$ $\mathrm{mL}$, insufficiency $<30 \mathrm{ng} / \mathrm{mL}$ and deficiency were $<20 \mathrm{ng} / \mathrm{mL}$. Patients were stratified and analysed.

Results Between 2009 and 2018, there were 4426 patients who had $25(\mathrm{OH})$ Vit $\mathrm{D}$ testing. Vitamin $\mathrm{D}$ testing increased significantly $(p<0.001)$ in the past 10 years. $43 \%$ of patients had sufficient 25(OH)Vit D levels, $41 \%$ had insufficient levels and $15 \%$ had deficient levels.

Conclusion More frequent testing has led to an increased identification of patients with insufficient and deficient $25(\mathrm{OH})$ Vit D levels. We found over $50 \%$ of patients tested were found to have $25(\mathrm{OH})$ Vit $D$ levels under $30 \mathrm{ng} / \mathrm{mL}$. There should be an increased awareness of patients with orthopaedic problems who may present with $25(\mathrm{OH})$ insufficiency.

\section{INTRODUCTION}

There is an increasing awareness of the importance of vitamin D for the normal
Strengths and limitations of this study

- Large longitudinal study in single orthopaedic and sports medicine centre.

- Able to assess vitamin D testing and trends over 10year period.

- Retrospective study design.

- Most of our patients did not have 25(OH)D testing, and we can only report on those who did.

> Cannot assess vitamin D intake or treatment.

development of the paediatric skeleton and for maintaining musculoskeletal health. Historically, the primary source for vitamin D was from exposure to the sun with limited amounts coming from dietary intake, however with increasing use of sun protection methods to avoid skin cancer, the absorption of vitamin $\mathrm{D}$ from the sun is decreasing. ${ }^{1}$ In the musculoskeletal system, vitamin D maintains the skeletal calcium balance by promoting calcium and phosphorus absorption in the gastrointestinal system, improving calcium retention in the renal system and improving mineralisation and strength to the bone. ${ }^{23}$ Risk factors for vitamin D deficiency include breast feeding without vitamin D supplementation, increased skin pigmentation, obesity, older age, geographic latitude, decreased dietary vitamin $D$ intake and decreased sun exposure. ${ }^{34}$ One study found that the prevalence of vitamin $\mathrm{D}$ deficiency $(25(\mathrm{OH}) \mathrm{D}<20$ $\mathrm{ng} / \mathrm{mL}$ ) at the end of winter in healthy adults who drink milk and take a daily multivitamin was as high as $32 \% .^{5}$ The rates of $25(\mathrm{OH}) \mathrm{D}$ deficiency in adolescents have been reported to range from $17 \%$ to $47 \%{ }^{6-8}$ Vitamin D deficiency has been shown to be a risk factor for severe fractures in children. ${ }^{9}$

Universal screening for vitamin D is not currently recommended in healthy children. 
Screening is currently only recommended for children at risk for vitamin D deficiency. ${ }^{10}$ The appropriate blood test to assess vitamin D status is 25-hydroxyvitamin D (25 (OH) $\mathrm{D})$, the storage form of vitamin $\mathrm{D}$; the other available test for 1,25-dihydroxyvitamin $\mathrm{D}(1,25(\mathrm{OH}) \mathrm{D})$, the active form of vitamin $\mathrm{D}$, which is recommended for patients with dysregulated vitamin $\mathrm{D}$ metabolism (eg, renal disease) should not be utilised for assessing vitamin D status in most people. ${ }^{10}$ The serum $25(\mathrm{OH}) \mathrm{D}$ level reflects the amount of vitamin D (cholecalciferol and ergocalciferol) obtained from the diet and vitamin supplementation as well as the generation of cholecalciferol (vitamin D3) in the skin on exposure to ultraviolet B radiation; this also reflects the level of body stores of vitamin D. The Endocrine's Society's Clinical Practice Guideline defines vitamin $\mathrm{D}$ deficiency as $25(\mathrm{OH}) \mathrm{D}<20 \mathrm{ng} / \mathrm{mL}$, insufficiency as $21-29 \mathrm{ng} / \mathrm{mL}$ and sufficiency as $30-100$ $\mathrm{ng} / \mathrm{mL} .{ }^{1011}$ The Institute of Medicine has different levels of $25(\mathrm{OH})$ which constitute deficiency, but this debate is outside the scope of this paper. ${ }^{11} 12$

Children with $25(\mathrm{OH}) \mathrm{D}$ deficiency often present to the orthopedist with musculoskeletal problems including fractures, bony pain, skeletal deformity such as genu valgum/varum and radiographic changes consistent with rickets. ${ }^{13}$ There have been inconsistent reports of the impact of $25(\mathrm{OH}) \mathrm{D}$ in the orthopaedic literature, however, many studies have found association of low $25(\mathrm{OH}) \mathrm{D}$ with increased odds for fractures, ${ }^{14}{ }^{15}$ lower limb deformities, ${ }^{13}$ female athlete triad, ${ }^{16}$ slipped capital femoral epiphysis ${ }^{17}$ and recently an increasing recognition of its role in progression and pathogenesis of scoliosis. ${ }^{18}$ Vitamin D deficiency has also been reported in patients with neuromuscular diseases, including cerebral palsy and may contribute to bone fragility particularly in these non-ambulatory patients. ${ }^{19-21}$

Providers in our Paediatric Orthopaedic and Sports Medicine department have become increasingly aware of the possibility of $25(\mathrm{OH}) \mathrm{D}$ deficiency, its prevalence in our northeastern US location, and the problems associated with musculoskeletal health. The purpose of this study was to assess our utilisation of $25(\mathrm{OH}) \mathrm{D}$ testing over the past 10 years and to evaluate the level of $25(\mathrm{OH})$ $\mathrm{D}$ insufficiency and deficiency in various populations of patients seen in our department. In addition, risk factors for insufficiency and deficiency were assessed.

\section{METHODS}

\section{Cohort selection}

After obtaining approval from the hospital's Institutional Review Board, a retrospective chart review of patients treated in the Orthopaedic and Sport Medicine Centres at a large paediatric academic centre in the northeast was conducted. Data were collected from our hospital based medical records electronic query system from January 2009 to December 2018. Patients were included if they met the following criteria: (1) age 0-20 years, (2) treated in the Orthopaedic or Sports Medicine Centres and (3) had a serum 25(OH)D level collected at the time of the clinic visit. Exclusion criteria: (1) known skeletal dysplasia or metabolic disorders such as osteogenesis imperfecta or hypophosphatemic rickets. Patients were grouped into four broad categories based on diagnosis: (1) cerebral palsy/neuromuscular disorders, (2) sports medicine, (3) spine and (4) general paediatric orthopaedics (not otherwise specified above). Patients were grouped into categories based on the type of physician seen at the time of serum $25(\mathrm{OH}) \mathrm{D}$ collection: patients seen by a sports medicine physician were placed into the category of 'sports'; patients seen by the spine team were placed into 'spine'; patients seen by our neuromuscular physicians were placed into the category 'cerebral palsy/neuromuscular disorders' and all other patients seen by our orthopaedic providers, including our bone health clinic endocrinologists, were placed into 'general'. Our practice has considerable subspecialisation within paediatric orthopaedics to make this differentiation possible. Due to the nature of our medical records electronic query system, individual patient diagnoses for the visit were not available. A sport medicine provider may see a patient with spondylolysis and collect their $25(\mathrm{OH}) \mathrm{D}$ and that patient will be categorised as a 'sports' patient; similarly, a spine specialist may see a soccer player with scoliosis, and they will be categorised as 'spine'.

Additionally, we searched our hospital-based medical records electronic query system for all unique patients (no repeat visits) seen in the Department of Orthopaedics and Sports Medicine each year during this time to serve as a volume control for the $25(\mathrm{OH}) \mathrm{D}$ testing.

\section{Data collection and classification}

Demographic and laboratory data: limited demographic data were collected from the database including age, sex, ethnicity, body mass index, date of visit, orthopaedic treating provider and serum 25(OH)D levels $(\mathrm{ng} / \mathrm{mL})$. All serum 25 $(\mathrm{OH}) \mathrm{D}$ levels were processed at the same laboratory at our large paediatric academic centre using mass spectrometry. While there is some debate over the definition of $25(\mathrm{OH}) \mathrm{D}$ sufficiency, insufficiency and deficiency in children, ${ }^{1022}$ in this study, we classified sufficiency of $25(\mathrm{OH}) \mathrm{D}$ based on the Endocrine Society's recommendation: deficiency $<20 \mathrm{ng} / \mathrm{mL}$, insufficiency $20-<30 \mathrm{ng} / \mathrm{mL}$ and sufficiency $\geq 30 \mathrm{ng} / \mathrm{mL} .{ }^{10}$ We also did an additional analysis of patients with a level $<10 \mathrm{ng} /$ $\mathrm{mL}$. Patients were categorised into the seasons in which the $25(\mathrm{OH}) \mathrm{D}$ testing was completed as follows: spring (1 March- 31 May), summer (1 June-30 August), fall (1 September-30 November) and winter (1 December-29 February). Body mass index (BMI) percentile was categorised according to the WHO categories for children adjusted for sex and age as: underweight $(<5$ th percentile), healthy weight (between 5th and 85th percentile), overweight ( $\geq 85$ th but $<95$ th percentile) and obese ( $\geq 95$ th percentile). Children under the age of 2 years did not have BMI percentiles calculated and were therefore 
Table 1 Cohort summary $(n=4426)$

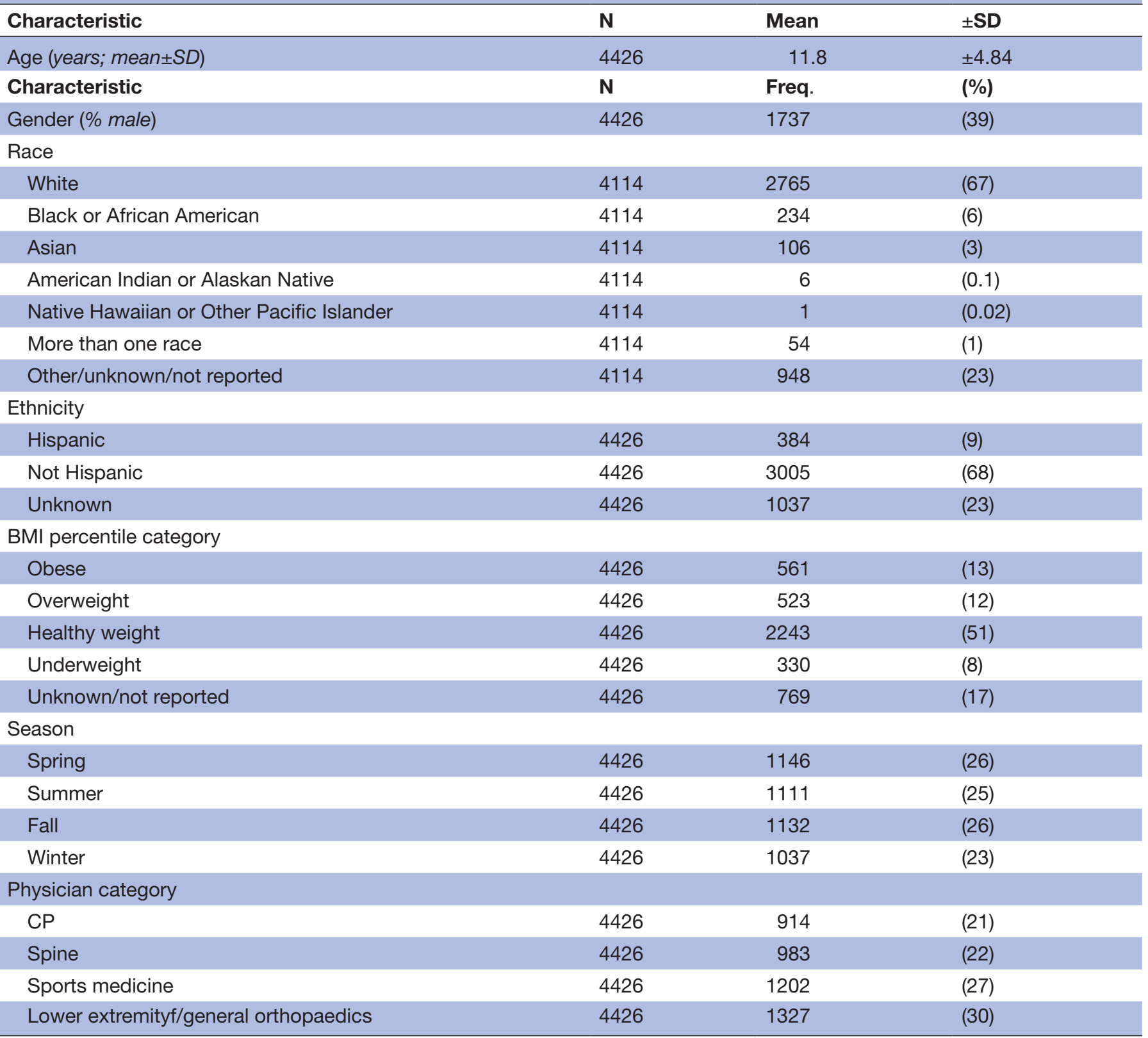

Demographic and clinical characteristics of patients tested for $25(\mathrm{OH})$ vitamin $D$ levels $(n=4426)$.

$\mathrm{BMI}$, body mass index; CP, cerebral palsy.

listed in the 'unknown' category which was not included in the multivariable analysis.

\section{Data analysis}

Descriptive statistics and graphical displays were used to describe the patient cohort. Associations between the four different $25(\mathrm{OH}) \mathrm{D}$ levels and patient characteristics were assessed by Spearman's rank correlation analysis, Cochran Armitage test for trend or Friedmans test, as appropriate. Univariate logistic regression was used to assess associations between insufficient and sufficient $25(\mathrm{OH}) \mathrm{D}$ levels and patient characteristics. Furthermore, the multivariable logistic regression analysis was used to assess associations between patient characteristics and the likelihood of testing insufficient in $25(\mathrm{OH}) \mathrm{D}$ or testing sufficient for $25(\mathrm{OH}) \mathrm{D}$. Since multiple comparisons were conducted for each cohort characteristic, p-values were adjusted using a Bonferroni adjustment and only adjusted p-values are reported. Statistical significance was set at $\mathrm{p}<0.05$.

\section{RESULTS}

\section{Cohort characteristics}

From 2009 to 2018, there were a total of 4426 children age birth to 20 years who had their $25(\mathrm{OH}) \mathrm{D}$ levels tested. Initial query populated a list of 4527 unique patients 


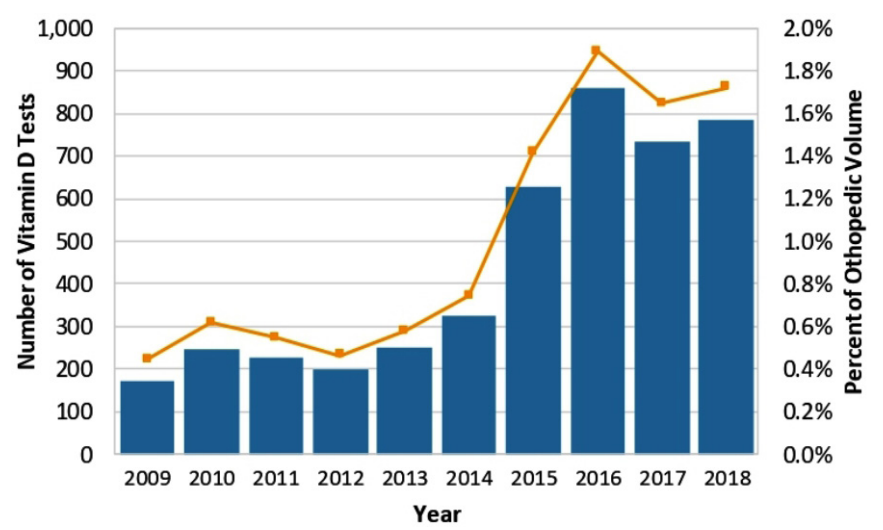

Figure 1 Frequency of $25(\mathrm{OH})$ Vit $\mathrm{D}$ tests reported as the number of tests and the percent $25(\mathrm{OH})$ Vit $D$ tests per orthopaedic volume per year.

(several patients had vitamin $\mathrm{D}$ tested more than once but were only included once in the study); 101 patients excluded because of age over 20 years old. The majority of the cohort was female $(\mathrm{n}=2689 / 4426,61 \%)$, white $(\mathrm{n}=2765 / 4114,67 \%)$ and non-Hispanic $(\mathrm{n}=3005 / 4426$, $68 \%$ ) (table 1). 25( $\mathrm{OH}) \mathrm{D}$ levels for the cohort ranged from $<2$ to $151 \mathrm{ng} / \mathrm{mL}$. The lowest value $(<2 \mathrm{ng} / \mathrm{mL})$ was in a patient noted to have active rickets, and his level normalised after appropriate supplementation. The highest level $(151 \mathrm{ng} / \mathrm{mL})$ was in a premature infant who was on vitamin $\mathrm{D}$ supplementation in addition to formula in her G-tube; the levels normalised after the supplementation was discontinued.

From 2009 to 2018, there was 3.9-fold increase in $25(\mathrm{OH}) \mathrm{D}$ testing. In 2009, we tested 171 patients for $25(\mathrm{OH}) \mathrm{D}$, about $0.4 \%$ of the orthopaedic volume, compared with 787 patients in 2018 , about $1.7 \%$ of the orthopaedic volume. There was an increase in the rate of 25(OH)D testing between 2014 and 2015. From 2009 to 2014 , the average rate of testing was $0.6 \%$ and between 2015 and 2018, the rate of testing significantly increased to an average of $1.7 \%$ of orthopaedic patients $(p<0.001)$ (figure 1).

Forty-three percent of the cohort had $25(\mathrm{OH}) \mathrm{D}$ levels of at least $30 \mathrm{ng} / \mathrm{mL}(1925 / 4426), 41 \%$ had $25(\mathrm{OH}) \mathrm{D}$ levels between 20 and $29.9 \mathrm{ng} / \mathrm{mL}(1836 / 4426), 14 \%$ had $25(\mathrm{OH}) \mathrm{D}$ levels between 10 and $19.9 \mathrm{ng} / \mathrm{mL}(600 / 4426)$ and $1 \%$ had $25(\mathrm{OH}) \mathrm{D}$ levels below $10 \mathrm{ng} / \mathrm{mL}(65 / 4426)$ (table 2). There was an inverse relationship present between age and 25(OH)D level group $(\mathrm{p}=0.006)$ and varying distribution of $25(\mathrm{OH}) \mathrm{D}$ level groups were across increasing age groups (figure 2). There were also differences detected across BMI percentile categories and $25(\mathrm{OH}) \mathrm{D}$ levels $(\mathrm{p}<0.001)$ (figure 3$)$. Similar trends in the distribution of $25(\mathrm{OH}) \mathrm{D}$ levels were seen between spring and winter (colder seasons) and similar trends were seen in summer and fall (warmer seasons) (figure 4). While no significant difference was detected across the seasons, the distribution of $25(\mathrm{OH}) \mathrm{D}$ was different when comparing cold to warm seasons $(p<0.001)$. Similarly, while there was no significant difference detected across physician groups, it was found that spine physicians had disproportional higher numbers of patients with low $25(\mathrm{OH}) \mathrm{D}$ levels as compared with the other physicians $(\mathrm{p}<0.001)$; figure 5 .

Table 2 Demographic and clinical characteristics by $25(\mathrm{OH})$ Vitamin D groups $(\mathrm{n}=4426)$

Multivariable analysis revealed that patients who were older $(\mathrm{p}<0.001)$, non-white $(\mathrm{p}<0.001)$, obese $(\mathrm{p}<0.001)$, visited a spine physicians $(\mathrm{p}<0.001)$ or whose level was measured during the colder seasons $(\mathrm{p}<0.001)$ had an increased likelihood of $25(\mathrm{OH}) \mathrm{D}$ deficiency $(<20 \mathrm{mg} /$ $\mathrm{mL}$ ). Moreover, it was found that for each additional year of age, patients had a $7 \%$ increase in the odds of testing $25(\mathrm{OH}) \mathrm{D}$ insufficient $(\mathrm{OR}=1.0795 \%, \mathrm{CI}=1.04$ to 0.1 .10 , $\mathrm{p}<0.001)$. Patients who were obese had 2.4 times greater odds of testing insufficient for $25(\mathrm{OH}) \mathrm{D}(\mathrm{OR}=2.37,95 \%$ $\mathrm{CI}=1.74$ to $3.23, \mathrm{p}<0.001)$. Patients tested in the colder months (winter or spring) had 2.1 times greater odds of testing insufficient for $25(\mathrm{OH}) \mathrm{D}(\mathrm{OR}=2.08,95 \% \mathrm{CI}=1.62$ to $2.66, \mathrm{p}<0.001)$. Patients seen by spine physicians had 1.6 times greater odds of testing insufficient for $25(\mathrm{OH})$ D $(\mathrm{OR}=1.64,95 \% \mathrm{CI}=1.26$ to $2.13, \mathrm{p}<0.001)$. Non-white patients had 3.2 times greater odds of testing insufficient for $25(\mathrm{OH}) \mathrm{D}(\mathrm{OR}=3.2595 \% \mathrm{CI}=2.44$ to $4.33, \mathrm{p}<0.001)$.

\section{DISCUSSION}

This study demonstrates a steady increase in the number of $25(\mathrm{OH}) \mathrm{D}$ measurements obtained for children treated for musculoskeletal disorders in our institution. In those patients tested through our Department of Orthopaedics and Sports Medicine, we found only $43 \%$ of patients with sufficient levels of serum $25(\mathrm{OH}) \mathrm{D}$; a surprising $41 \%$ were insufficient, and $15 \%$ were found to be deficient. Other research has shown variable levels of $25(\mathrm{OH}) \mathrm{D}$ insufficiency and deficiency, ranging from $40 \%$ to $90 \%{ }^{23-25}$ and our findings are consistent with this wide range. Davies et $a l^{22}$ found that $32 \%(\mathrm{n}=60)$ of the patients presenting to a paediatric orthopaedic clinic in the UK over a 3year period had 25(OH)D insufficiency, while $8 \%(\mathrm{n}=15)$ had a deficiency. ${ }^{22}$ In a retrospective review of all patients seen in a different orthopaedic clinic in the UK in 2010, investigators found that $88 \%(\mathrm{n}=103)$ of patients had below normal 25(OH)D levels $(<30 \mathrm{ng} / \mathrm{mL})$. These low levels were often found in children presenting with limb or back pain. ${ }^{26}$ Szalay et $a l^{23}$ reported a $40 \%$ rate of $25(\mathrm{OH})$ $\mathrm{D}$ deficiency in the orthopaedic patients presenting to their clinic in the American Southwest where more sun exposure typically would be expected. ${ }^{23}$ Parry $e t ~ a l^{24}$ evaluated the serum $25(\mathrm{OH}) \mathrm{D}$ levels of 70 patients prior to elective orthopaedic procedures in Texas and found $90 \%$ were deficient or insufficient. We also found a higher rate of $25(\mathrm{OH}) \mathrm{D}$ deficiency in patients of non-white race, Hispanic ethnicity, presence of obesity, those tested by spine physicians and those in the colder months. It is still not clear what level of low $25(\mathrm{OH}) \mathrm{D}$ leads to orthopaedic problems, and this study was not able to determine this; different orthopaedic problems likely have different 
Table 2 Cohort characteristics by 25(OH)Vit D level group

\begin{tabular}{|c|c|c|c|c|c|c|c|c|c|c|}
\hline \multirow[b]{2}{*}{ Characteristic } & \multicolumn{2}{|c|}{$\begin{array}{l}\text { Deficiency } \\
0-9.9 \mathrm{ng} / \mathrm{mL} \\
(\mathrm{n}=65)\end{array}$} & \multicolumn{2}{|c|}{$\begin{array}{l}\text { Deficiency } \\
10-19.9 \mathrm{ng} / \mathrm{mL} \\
(\mathrm{n}=600)\end{array}$} & \multicolumn{2}{|c|}{$\begin{array}{l}\text { Insufficiency } \\
20-29.9 \mathrm{ng} / \mathrm{mL} \\
(\mathrm{n}=1836)\end{array}$} & \multicolumn{2}{|c|}{$\begin{array}{l}\text { Sufficiency } \\
30+n g / m L \\
(n=1925)\end{array}$} & \multirow[b]{2}{*}{ P value* } & \multirow[b]{2}{*}{$\mathbf{P}$ value } \\
\hline & Freq. & $(\%)$ & Freq. & $(\%)$ & Freq. & (\%) & Freq. & $(\%)$ & & \\
\hline $\begin{array}{l}\text { Age (years; mean } \\
\text { SD) }\end{array}$ & 13.1 & 4.39 & 12.6 & 3.96 & 11.8 & 4.54 & 11.5 & 5.32 & 0.006 & $<0.001$ \\
\hline Gender (\% male) & 40 & (62) & 241 & $(40)$ & 705 & (38) & 751 & (39) & 0.11 & 0.08 \\
\hline White & 20 & (35) & 270 & (49) & 1157 & (68) & 1318 & (73) & $<0.001$ & $<0.001$ \\
\hline $\begin{array}{l}\text { Black or African } \\
\text { American }\end{array}$ & 10 & (17) & 59 & (11) & 106 & (6) & 59 & (3) & & \\
\hline Asian & 1 & (2) & 23 & (4) & 52 & (3) & 30 & (2) & & \\
\hline $\begin{array}{l}\text { American Indian } \\
\text { or Alaskan Native }\end{array}$ & 0 & (0) & 0 & (0) & 4 & (0) & 2 & (0) & & \\
\hline $\begin{array}{l}\text { More than one } \\
\text { race }\end{array}$ & 1 & (2) & 10 & (2) & 25 & (2) & 18 & (1) & & \\
\hline Other/unknown & 26 & $(45)$ & 187 & (34) & 360 & $(21)$ & 375 & (21) & & \\
\hline \multicolumn{11}{|l|}{ Ethnicity } \\
\hline Hispanic & 9 & (14) & 94 & (16) & 153 & (8) & 128 & (7) & $<0.001$ & 0.004 \\
\hline Not Hispanic & 40 & (62) & 360 & (60) & 1267 & (69) & 1349 & (70) & & \\
\hline Unknown & 16 & $(25)$ & 146 & (24) & 427 & (23) & 448 & (23) & & \\
\hline \multicolumn{5}{|c|}{ BMI percentile category } & & & & & $<0.001$ & $<0.001$ \\
\hline Spring & 22 & (34) & 200 & (33) & 495 & $(27)$ & 429 & (22) & & \\
\hline Summer & 9 & (14) & 99 & (17) & 424 & (23) & 579 & (30) & & \\
\hline Fall & 16 & $(25)$ & 127 & $(21)$ & 451 & $(25)$ & 538 & $(28)$ & & \\
\hline Winter & 18 & (28) & 174 & (29) & 466 & (25) & 379 & (20) & & \\
\hline Physician category & & & & & & & & & 0.27 & 0.97 \\
\hline $\mathrm{CP}$ & 16 & (25) & 107 & (18) & 344 & (19) & 447 & (23) & & \\
\hline Spine & 24 & $(37)$ & 180 & (30) & 427 & $(23)$ & 352 & (18) & & \\
\hline Sports medicine & 7 & (11) & 105 & (18) & 486 & $(27)$ & 604 & (31) & & \\
\hline $\begin{array}{l}\text { Lower extremity/ } \\
\text { general } \\
\text { orthopaedics }\end{array}$ & 18 & $(28)$ & 208 & (35) & 579 & (32) & 522 & $(27)$ & & \\
\hline
\end{tabular}

Demographic and clinical characteristics by $25(\mathrm{OH})$ Vitamin D groups $(n=4426)$.

${ }^{*} \mathrm{P}$-value calculated for comparison of four ordinal groups.

$\dagger P$-value calculated for comparison of binary groups (deficient ( $<20 \mathrm{ng} / \mathrm{mL}$ ) versus insufficient/sufficient $(20+\mathrm{ng} / \mathrm{mL}) 25(\mathrm{OH}) \mathrm{Vit} \mathrm{D}$ levels).

BMI, body mass index; CP, cerebral palsy. 


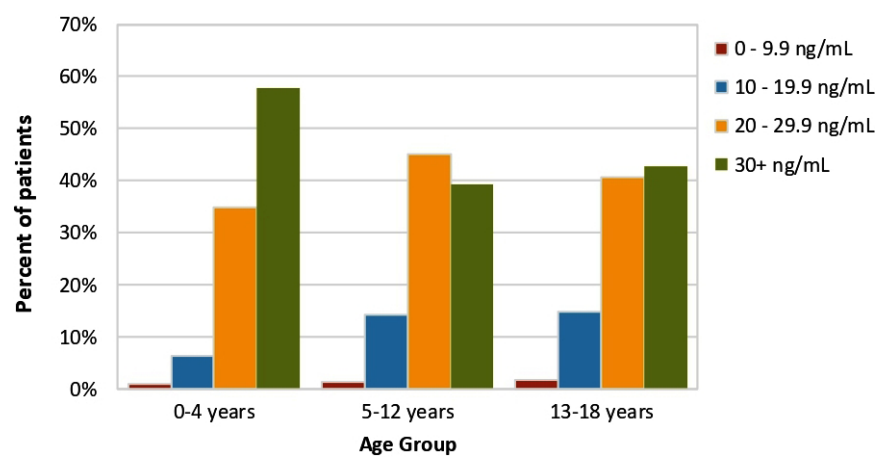

Figure 2 Distribution of 25(OH)Vit D laboratory values by age for the cohort $(n=4426)$.

thresholds where low serum 25(OH)D levels become contributory.

The association of $25(\mathrm{OH}) \mathrm{D}$ deficiency with idiopathic scoliosis has recently been shown. ${ }^{18}$ Several studies have shown that increased scoliosis curve is associated with low serum $25(\mathrm{OH}) \mathrm{D}$ levels. ${ }^{27}{ }^{28}$ The mechanism of the influence of $25(\mathrm{OH}) \mathrm{D}$ on scoliosis is not known and may be multifactorial. ${ }^{18}{ }^{27}$ In our study, patients whose $25(\mathrm{OH}) \mathrm{D}$ was tested by a spine specialist had a higher rate of deficiency. This is not surprising given the negative correlation seen between $25(\mathrm{OH}) \mathrm{D}$ levels and curve progression. $25(\mathrm{OH}) \mathrm{D}$ testing is routine in our institution prior to surgery for idiopathic scoliosis.

Increased risk for $25(\mathrm{OH}) \mathrm{D}$ deficiency in darker skinned individuals ('non-white'), particularly for the African-American population, has also been previously reported in other studies. ${ }^{424}$ It is not clear whether or not the $25(\mathrm{OH}) \mathrm{D}$ deficiency in African-Americans is associated with decreased bone mineral density and increased risk for fractures in this population. ${ }^{14}$ In our study, we also found a higher rate of $25(\mathrm{OH}) \mathrm{D}$ deficiency among patients of non-white race and Hispanic ethnicity.

$25(\mathrm{OH}) \mathrm{D}$ deficiency in overweight or obese children has been demonstrated in several studies. ${ }^{62}$ This likely has multifactorial influences including decreased $25(\mathrm{OH})$ D intake ${ }^{29}$ as well as possible sequestration of vitamin D in adipose tissue causing the blood level of $25(\mathrm{OH}) \mathrm{D}$ to under-represent the total body levels. ${ }^{6}$ In our study, we

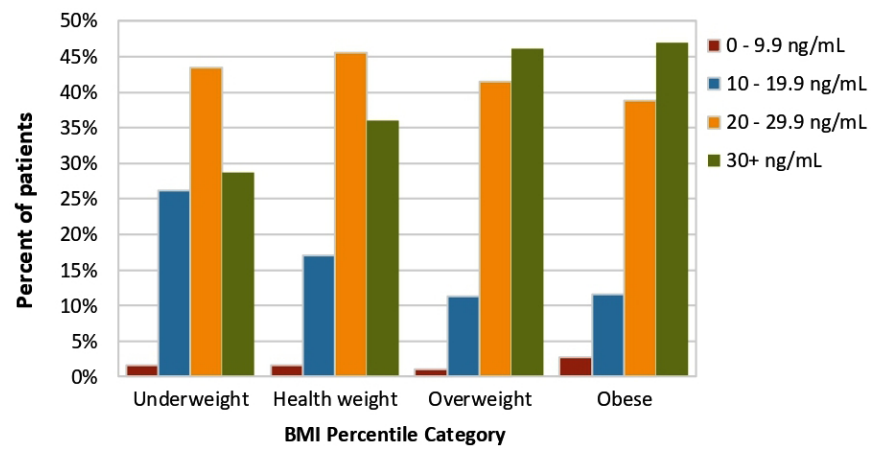

Figure 3 Distribution of 25(OH)Vit D groups by BMI category for the cohort $(n=4426)$. BMl, body mass index.

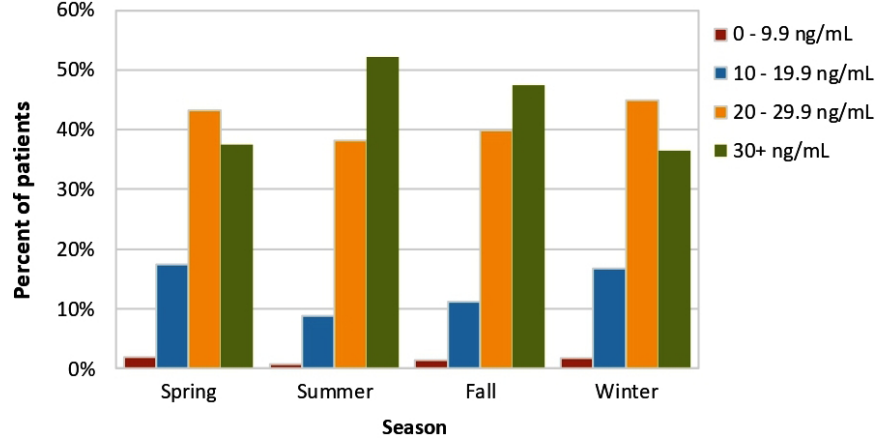

Figure 4 Distribution of 25(OH)Vit $\mathrm{D}$ groups by season for the cohort $(n=4426)$.

also found a higher rate of $25(\mathrm{OH}) \mathrm{D}$ deficiency among obese patients.

Seasonal variation in serum $25(\mathrm{OH}) \mathrm{D}$ has been shown in many studies, and $25(\mathrm{OH}) \mathrm{D}$ levels are lower in the winter months. ${ }^{624}$ This includes studies done in locations such as the southern USA where seasonal variation may be considered less of a factor. ${ }^{624}$ This is likely due to the decreased sun exposure during these months. We also found a higher rate of $25(\mathrm{OH}) \mathrm{D}$ deficiency in patients in the winter and spring months.

Currently, there are no recommendations for routine screening or routine supplementation of vitamin D for children and adolescents, although there is increasing recognition that this should be strongly considered. ${ }^{102530}$ Should we recommend routine screening or supplementation of all children in Massachusetts, the northeast USA, northern climates or all children in general? ${ }^{31}$ Minkowitz et al recommend 25( $\mathrm{OH}) \mathrm{D}$ levels be checked on all patients who sustain a fracture to increase compliance of supplementation. However, perhaps all patients should receive supplementation, and that may obviate the need for screening? ${ }^{3032}$ While many paediatricians are aware of the problem of vitamin D deficiency, few recommend routine supplementation. ${ }^{3033}$ The cost of testing on a population basis can be high ${ }^{34}$ and this would support more routine supplementation; however, routine adherence to a vitamin D supplementation regime has been difficult for many families. ${ }^{35}$ There have also been recent endorsements from the American Academy of Paediatrics

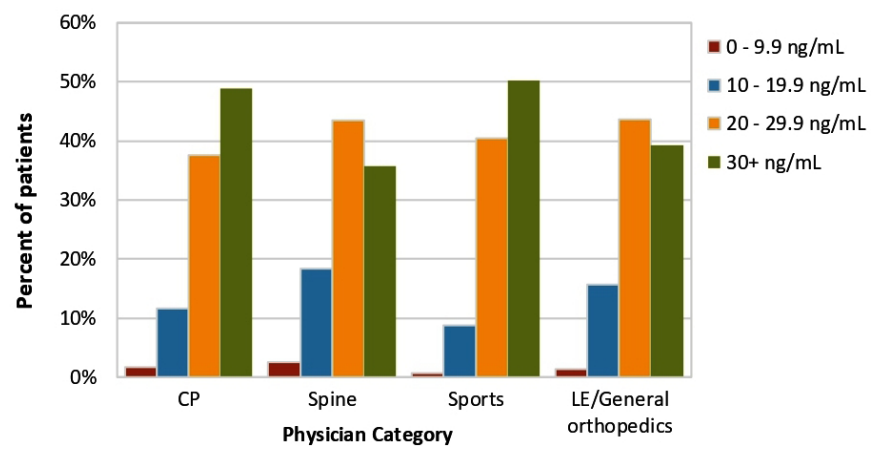

Figure 5 Distribution of 25(OH)Vit D groups by physician category for the cohort $(n=4426)$. CP, cerebral palsy; LE, lower extremity. 
for higher vitamin D supplementation at higher doses ${ }^{34}$ instead routine testing for vitamin $\mathrm{D}$ deficiency.

Our study had several limitations. Most of our patients did not have 25(OH)D testing, and we can only report on those who did; these patients were clearly selected by their treating physician to be at some risk for $25(\mathrm{OH}) \mathrm{D}$ deficiency and some physicians were more likely to test to assess for this possible deficiency. We cannot stratify by diagnosis because the data system we use cannot isolate the diagnosis associated with that visit (most patients have multiple diagnoses). We also cannot assess treatment because, due to a 3-day delay in the $25(\mathrm{OH}) \mathrm{D}$ laboratory testing, patients were contacted after their visit and often a multivitamin or over-the-counter vitamin $\mathrm{D}$ was prescribed; this is often not reflected in the medical record. We also do not know if the children tested were taking vitamin D supplement (or a multivitamin containing vitamin D) prior to testing, using sunscreen or obtaining significant vitamin D in their diet. Finally, we could not identify patients who had conditions affecting vitamin D intake, absorption and metabolism or children taking drugs that interfere with vitamin $\mathrm{D}$ metabolism; this relatively small cohort of patients was therefore included in this study and would affect the analyses.

\section{CONCLUSION}

It is important to recognise that children in the northeast USA are 'at risk' for low vitamin D and may present with orthopaedic problems along with their insufficiency or deficiency. We as providers need to recognise the risks of $25(\mathrm{OH}) \mathrm{D}$ deficiency in this population and the need for either increased supplementation or screening of $25(\mathrm{OH}) \mathrm{D}$ levels in this group.

Contributors In the writing of this manuscript, Dr SM served as the principal investigator and author, with considerable assistance from Drs KA and RDF. Mr NS served as data organiser and assisted in manuscript preparation. Ms PM and Ms LF analysed the data. Dr MG (spine) and Dr IAH (endocrinology) served as specific experts in the manuscript review process. SM is respondible for the overall content as the guarantor and accepts full responsibility for the work and conduct of the study.

Funding The authors have not declared a specific grant for this research from any funding agency in the public, commercial or not-for-profit sectors.

Competing interests None declared.

Patient and public involvement Patients and/or the public were not involved in the design, or conduct, or reporting or dissemination plans of this research.

\section{Patient consent for publication Not required.}

Ethics approval This study was originally approved and accepted by the Boston Children's Hospitals (BCH) Internal Review Board (IRB). The IRB approval number at BCH is IRB-P00013551. We applied and obtained a waiver of consent for this retrospective study as contacting over 4000 patients who may have left our institution for treatment would have significantly impacted our patient cohort and would not be reasonably feasible to contact and consent.

Provenance and peer review Not commissioned; externally peer reviewed.

Data availability statement Data are available upon reasonable request. We are open to sharing our raw data from which we based this study on, upon request. Data are available by emailing SM and NS at susan.mahan@childrens.harvard.edu and nicholas.sullivan@childrens.harvard.edu, respectively.

Open access This is an open access article distributed in accordance with the Creative Commons Attribution Non Commercial (CC BY-NC 4.0) license, which permits others to distribute, remix, adapt, build upon this work non-commercially, and license their derivative works on different terms, provided the original work is properly cited, appropriate credit is given, any changes made indicated, and the use is non-commercial. See: http://creativecommons.org/licenses/by-nc/4.0/.

ORCID iD

Susan Mahan http://orcid.org/0000-0003-3769-0765

\section{REFERENCES}

1 Holick M. The global D-Lemma: the vitamin D deficiency pandemic even in sun-drenched countries. J Clin Sci Res 2018;7:101.

2 Charoenngam N, Shirvani A, Holick MF. Vitamin D for skeletal and non-skeletal health: what we should know. J Clin Orthop Trauma 2019;10:1082-93.

3 Holick MF. The vitamin D epidemic and its health consequences. $J$ Nutr 2005;135:2739S-48.

4 Saintonge S, Bang H, Gerber LM. Implications of a new definition of vitamin $\mathrm{D}$ deficiency in a multiracial us adolescent population: the National health and nutrition examination survey III. Pediatrics 2009;123:797-803.

5 Tangpricha V, Pearce EN, Chen TC, et al. Vitamin D insufficiency among free-living healthy young adults. Am J Med 2002;112:659-62.

6 Dong Y, Pollock N, Stallmann-Jorgensen IS, et al. Low 25-hydroxyvitamin D levels in adolescents: race, season, adiposity, physical activity, and fitness. Pediatrics 2010;125:1104-11.

7 Cole CR, Grant FK, Tangpricha V, et al. 25-Hydroxyvitamin D status of healthy, low-income, minority children in Atlanta, Georgia. Pediatrics 2010;125:633-9.

8 Au LE, Rogers GT, Harris SS, et al. Associations of vitamin D intake with 25 -hydroxyvitamin $D$ in overweight and racially/ethnically diverse US children. $J$ Acad Nutr Diet 2013;113:1511-6.

9 Minkowitz B, Cerame B, Poletick E, et al. Low vitamin D levels are associated with need for surgical correction of pediatric fractures. $J$ Pediatr Orthop 2017:37:23-9.

10 Holick MF, Binkley NC, Bischoff-Ferrari HA, et al. Evaluation, treatment, and prevention of vitamin $D$ deficiency: an endocrine Society clinical practice guideline. J Clin Endocrinol Metab 2011;96:1911-30.

11 Rosen CJ, Abrams SA, Aloia JF, et al. lom Committee members respond to endocrine Society vitamin D guideline. J Clin Endocrinol Metab 2012;97:1146-52.

12 Pilz S, Zittermann A, Trummer C, et al. Vitamin D testing and treatment: a narrative review of current evidence. Endocr Connect 2019;8:R27-43.

13 Voloc A, Esterle L, Nguyen TM, et al. High prevalence of genu varum/valgum in European children with low vitamin D status and insufficient dairy products/calcium intakes. Eur J Endocrinol 2010;163:811-7.

14 Ryan LM, Teach SJ, Singer SA, et al. Bone mineral density and vitamin $D$ status among African American children with forearm fractures. Pediatrics 2012;130:e553-60.

15 McCabe MP, Smyth MP, Richardson DR. Current concept review: vitamin D and stress fractures. Foot Ankle Int 2012;33:526-33.

16 Abrams GD, Feldman D, Safran MR. Effects of vitamin D on skeletal muscle and athletic performance. J Am Acad Orthop Surg 2018;26:278-85.

17 Judd J, Welch R, Clarke A, et al. Vitamin D deficiency in slipped upper femoral epiphysis. J Pediatr Orthoped 2016;36:247-52.

$18 \mathrm{Ng} \mathrm{S}$-Y, Bettany-Saltikov J, Cheung IYK, et al. The role of vitamin D in the pathogenesis of adolescent idiopathic scoliosis. Asian Spine $J$ 2018; 12:1127-45.

19 Talim B, Malaguti C, Gnudi S, et al. Vertebral compression in Duchenne muscular dystrophy following deflazacort. Neuromuscul Disord 2002;12:294-5.

20 Quinlivan R, Roper H, Davie M, et al. Report of a muscular dystrophy campaign funded workshop Birmingham, UK, January 16th 2004. osteoporosis in Duchenne muscular dystrophy; its prevalence, treatment and prevention. Neuromuscul Disord 2005;15:72-9.

21 Cohen M, Lahat E, Bistritzer T, et al. Evidence-Based review of bone strength in children and youth with cerebral palsy. J Child Neurol 2009;24:959-67.

22 Davies JH, Reed JM, Blake E, et al. Epidemiology of vitamin $D$ deficiency in children presenting to a pediatric orthopaedic service in the UK. J Pediatr Orthop 2011;31:10.1097/ BPO.0b013e31822f1af1:798-802.

23 Szalay EA, Tryon EB, Pleacher MD, et al. Pediatric vitamin D deficiency in a southwestern luminous climate. J Pediatr Orthoped 2011;31:469-73. 
24 Parry J, Sullivan E, Scott AC. Vitamin D sufficiency screening in preoperative pediatric orthopaedic patients. J Pediatr Orthop 2011;31:331-3.

25 Au LE, Economos CD, Goodman E, et al. Vitamin D intake and serum vitamin $\mathrm{D}$ in ethnically diverse urban schoolchildren. Public Health Nutr 2012;15:2047-53.

26 Foley GT, Yates EW, Wadia F, et al. Vitamin D: a poor screening tool for biochemical and radiological rickets. Acta Orthop Belg 2012;78:663-7.

27 Goździalska A, Jaśkiewicz J, Knapik-Czajka M, et al. Association of calcium and phosphate balance, vitamin D, PTH, and calcitonin in patients with adolescent idiopathic scoliosis. Spine 2016;41:10.1097/ BRS.0000000000001286:693-7.

28 Batista R, Martins DE, Hayashi LF, et al. Association between vitamin D serum levels and adolescent idiopathic scoliosis. Scoliosis 2014;9:045.

29 Alemzadeh R, Kichler J, Babar G, et al. Hypovitaminosis D in obese children and adolescents: relationship with adiposity, insulin sensitivity, ethnicity, and season. Metabolism 2008;57:10.1016/j. metabol.2007.08.023:183-91.

30 DelGiudice NJ, Street N, Torchia RJ, et al. Vitamin D prescribing practices in primary care pediatrics: underpinnings from the health belief model and use of web-based Delphi technique for instrument validity. J Pediatr Health Car. 2018;32(Current Opinion in Allergy and Clinical Immunology 2012;12:536-47.

31 Kumar J, Muntner P, Kaskel FJ, et al. Prevalence and associations of 25-hydroxyvitamin D deficiency in US children: NHANES 2001-2004. Pediatrics 2009;124:e362-70.

32 Sacheck JM, Van Rompay MI, Chomitz VR, et al. Impact of Three Doses of Vitamin D3 on Serum 25(OH)D Deficiency and Insufficiency in At-Risk Schoolchildren. J Clin Endocrinol Metabolism 2017;102:4496-505.

33 Misra M, Pacaud D, Petryk A, et al. On behalf of the D and TC of the LWPE. vitamin D deficiency in children and its management: review of current knowledge and recommendations. Pediatrics 2008;122:398-417.

34 Golden NH, Abrams SA. Optimizing bone health in children and adolescents. Pediatrics 2014;134:e1229-43.

35 LE A, Harris SS, Jacques PF, et al. Adherence to a vitamin D supplement intervention in urban schoolchildren. J Acad Nutr Diet 2013;114. 